\title{
Determinants of Foreign Direct Investment: New Granger Causality Evidence from Asian and African Economies
}

\author{
Olawumi D. Awolusi*, Theuns G. Pelser, Adedeji Saidi Adelekan \\ University of KwaZulu-Natal, South Africa \\ *awolusi@ukzn.ac.za
}

\begin{abstract}
Previous studies on the determinants of foreign direct investment (FDI) have predominantly focused on developed and emerging economies. However, there seem to be few studies concentrating on a comparative analysis of vast African and Asian countries. This paper analysed drivers of foreign direct investments (FDI) to Asian and African economies using a panel dataset from 1980 to 2013.This study used Granger causality test, under vector error correction modelling (VECM) to test for causality among the variables. While the drivers of FDI inflows were measured using five dimensions as proposed by Anyanwu; the dependent variable, FDI inflows, was proxied by the ratio of FDI flows to gross domestic product (GDP). Findings revealed that variables manifesting the determinants of FDI inflows positively affected FDI into these continents. Specifically, factors such as trade openness, macroeconomic condition, infrastructural development, and monetary union have positive and significant effect on FDI to Asian economies. No significant relationship was found between FDI inflows and market size to the Asian continent during the study period. On the other hand, trade openness, macroeconomic condition, market size and infrastructural development have positive and significant effects on FDI inflows to African economies although there was no significant relationship between FDI inflows and monetary union to the African continent during the study period. In fact, there were bi-directional relationships between FDI inflows and some of the determinants in both continents. Theoretically, this model provides predictive implications on improved FDI inflows, given the activities of critical variables manifesting as determinants of FDI inflows.
\end{abstract}

Keywords: Foreign Direct Investment, FDI Determinants, Granger Causality Test, Africa, Asia

\section{Introduction}

In the past few decades, globalisation has played a significant role in developing international trade and finance, and has facilitated the acceptance and integration of a number of the world's developing and emerging nations into the global economy (Hailu, 2010; Kimura and Todo, 2010). One of the cornerstones upon which globalisation has grown is foreign direct investment (FDI); flowing predominantly from high income western nations to these emerging economies (Pantelidis, Kyrkilis, and Nikolopoulos, 2012; Usman and Ibrahim, 2012; Anyanwu and Yameogo, 2015). Accordingly, FDI has evolved into a major source of development finance, contributing to the economic growth of many Asian and African economies (UNCTAD, 2015 , 2013). Specifically, FDI flows to developing countries considerably increased from a paltry annual average of $\$ 50$ billion in $1985-1995$ to over $\$ 233$ bn in 2004 (Anyanwu, 2012). Africa in particular has benefited enormously from FDI flows from both developed and emerging economies. Consequently, contrary to the earlier description of Africa as a 'forgotten continent', the rate of foreign direct investment (FDI) inflow to Africa has accelerated in the last two decades (Aregbesola, 2014; UNCTAD, 2013; Anyanwu, 2012). Apart from the inward FDI from developed and 'emerging economies', the rate of Africa-to-Africa internationalisation has also been impressive. Indigenous companies in Nigeria (such as Dangote, Glo, GT Bank and First Bank Plc.), South Africa (such as MTN, Standard Bank, and Shoprite), Kenya (Equity Bank and KCB) and Togo (Ecobank) can now boast having operations in more than two countries on the continent (UNCTAD, 2015). Although global FDI has made rapid increases in the past two decades, the growth in Africa has been most impressive. For example, after almost ten years of growth, inflows of FDI to Africa fell by 19 percent, from US\$72 billion in 2008 to US $\$ 44$ billion in 2010 due to the international financial and economic crisis experienced during this period (Aregbesola, 2014). However, a gradual recovery ensued from 2011 and FDI flows to Africa grew by $3.6 \%$ in 2013 to reach US\$57 billion from US $\$ 55$ billion in 2012, representing $3.9 \%$ of the global total stock (UNCTAD, 2015; UNCTAD, 2014; Anyanwu, 2012). 
However, regardless of the impressive performance of African countries, Asia continues to be the world's top recipient of foreign direct investment (FDI), accounting for nearly 30\% of global FDI inflows (UNCTAD, 2014). For example, with inflows at US $\$ 124$ billion, China was again ranked second in the world and narrowed the gap between itself and the United States, the country with the largest global inflows of FDI in 2014 (UNCTAD, 2015). Inflows to the Republic of Korea reached $\$ 12$ billion (the highest level since the mid-2000s), while FDI inflow to Taiwan rose to $\$ 4$ billion. Hong Kong (the second largest FDI recipient in East Asia) experienced only 2\% growth in FDI inflows to $\$ 77$ billion (UNCTAD, 2015). Although inflows to the Association of Southeast Asian Nations (ASEAN) countries rose by 7 per cent to $\$ 125$ billion in 2013, the rapid growth of FDI inflows to the regional grouping, from $\$ 47$ billion in 2009 to $\$ 118$ billion in 2012 , has now slowed (UNCTAD, 2014). India also experienced a 17\% increase in FDI inflows to $\$ 28$ billion in 2013 despite the macroeconomic uncertainties (UNCTAD, 2015).

Despite the impressive increase in FDI inflow to African and Asian economies, many of the previous studies on the determinants of foreign direct investment (FDI) inflow have been focused on the developed and emerging economies (Asiedu, 2002; Culem, 1988; Billington, 1999; Asheghian, 2004). While a few have concentrated on some countries in Africa (Alba, Park and Wang, 2009; Alfaro, Chanda, Kalemli-Ozcan and Sayek, 2004). However, there would appear to be very few studies which have made on a comparative analysis of vast African and Asian countries. Based on gaps identified by Asiedu (2002) and Lee and Tan (2006).this study seeks to fulfil this inquiry. In addition, there is a dearth of studies on FDI-determinants in the context of African versus Asian economies (Adam and Tweneboah, 2009; Billington, 1999). Furthermore, increasing globalisation as well as the shift towards free market ideology, necessitates an urgent call for studies to focus on causal relationship between FDI and the various determinants of FDI inflows into both developed and developing economies (Adam and Tweneboah, 2009; Hill, 2013; Porter, 1990). According to Lee and Tan (2006), despite the importance of FDI in conveying knowledge spillovers among countries, evidence regarding FDI inflows and its determinants has been mixed. Most existing literature has failed to prove a clear relationship between FDI inflows and the various determinants of these inflows. Corroborating their earlier stance, Lee and Tan (2006) also observed that despite strong empirical evidence supporting the influence of FDI inflows on economic growth and development in many developed and developing countries, evidence regarding the major determinants of FDI inflows has been mixed. Consequently, the main objective of this paper was to evaluate the determinants of FDI flows into the selected African and Asian economies. The specific objectives were achieved by testing the effects of the various institutional policy measures (trade openness, macroeconomic condition, market size, infrastructural development, and monetary union) on FDI inflows into the selected African and Asian economies between1980 and 2013.

The analytical focus was premised on developing countries, due to the submission of Anyanwu and Yameogo (2015). This paper, therefore argue that the practice of pooling developed and developing economies together in analysing the determinants of FDI inflows is inappropriate. This is on the premise that while developed economies have substantial amounts of two-way FDI flows, developing economies on the other hand are almost exclusively recipients of FDI flows (Aregbesola, 2014). This study was also premised on the fact that every country has the chance to recognize and develop its competitive advantages in its quest for more FDI inflows (Pelinescu, 2015; Awan, 2013). Improving FDI inflows are still very important to many Asian and African economies (Anyanwu, 2012), since many countries in these continents are still confronted with numerous problems (for example, poor infrastructural facilities, obsolete capital equipment, high public debt, high unemployment rates, and poverty) (Usman and Ibrahim, 2012; El-Wassal, 2012). Therefore, there is an urgent need to put in place strategies aimed at encouraging inflows of FDI in critical infrastructures and human capital development (Kimura and Todo, 2010; Kinda, 2010). In addition, a comparative study of the various determinants of FDI inflows using a panel regression technique of African and Asian economies will be beneficial to many countries in these continents, especially in the formulation of their trade and FDI policies (Pelinescu, 2015). This paper is divided into five sections. Section one is the introduction. Section two reviews the related literature, while section three describes the adopted methodology. Section four presents the results and the discussion of findings. The last section, section five presents the conclusion and the various implications of the study. 


\section{Literature Review}

Theoretical Framework: Dunning's (1981) (cited by Brouthers and Hennart, 2007) proposition is that a single theoretical perspective could not adequately explain FDI decisions or the mode of international expansion. Consequently, this study adopted the Ownership, Location Specific Advantage Considerations and the Internalisation Theories, as these theories have been identified as the major regulatory determinants of FDI behaviour in most developing countries (Dunning, 1981; Aregbesola, 2014). Dunning's Eclectic Theory identifies three components or conditions: ownership advantages, location advantages, and internalisation advantages (OLI). Dunning's Eclectic Theory is a transaction cost-based theory that seeks to explain the transfer, internationalisation, and firm-specific ownership advantages (Brouthers and Hennart, 2007).Hence, the theory suggests the importance of firm- and location- specific factors to explain the determinants of FDI inflows. Dunning's (1993) Eclectic or OLI (ownership, location, internalization) framework can be conceptualised as a tool that combines insights from resource-based (firm-specific), institutional (location) and transaction cost (internalisation) theories (Brouthers and Hennart, 2007). According to Billington (1999) and Aregbesola (2014).the location-specific advantage (e.g. markets, resources, technology, human capital, or favourable political economy) could be viewed from the perspectives of government policies (e.g. monetary and fiscal policies).This is based on the premise that FDI inflows to most countries will depend on the efficiency of the political institutions in the host country to formulate relevant investment-related fiscal and monetary policies (Barro and Sala-i-Martin, 1995; Steers and Nardon, 2006). Internalisation theory, on the other hand, is based on the premise that firms extract above-normal returns from FDI by internalising the host country's imperfections when their firm-specific assets cannot find comparable value elsewhere (Steers and Nardon, 2006; Stiglitz and Charlton, 2005). There are advantages to be had from exploiting imperfections in external markets, including the reduction of uncertainty and transaction costs in order to generate knowledge more efficiently and the reduction of state-generated imperfections such as tariffs, foreign exchange controls, and subsidies (Anyanwu and Erhijakpor, 2004; Anyanwu, 2006). Consequent upon this framework, Dunning (1993) identified four categories of motives for FDI: resource seeking, market seeking, efficiency seeking and strategic-asset seeking (Alsan, Bloom and Canning, 2006).

FDI and its Determinants: Previous studies to understand the determinants of FDI destination have produced mixed results. For example, Nnadozie and Osili (2004) find less robust evidence of the role of gross domestic product per capita on foreign domestic investment inflow, while GDP growth was alternatively found to have a significant impact on FDI inflow. In a similar study, Chakrabarti (2001) reviewed the findings of previous studies along a continuum of eight independent variables, namely: market size, labour cost, trade barrier, growth rate, economic openness, trade deficit, exchange rate volatility, and tax. In his findings, variables like market size, growth rate, and economic openness were found to be positively significant for FDI inflows in the studies evaluated. Market size was also found to play an important role in FDI inflows in the studies of Anyanwu $(1998,2011,2012)$, while market size was observed not to be significantly related to FDI inflows in the work of Kyereboah-Coleman and Agyire-Tettey (2008) in Ghana. This was corroborated by similar studies in the African context (Al-Sadig, 2009; Anyanwu, 2012). Another review by Asiedu (2002) compiled 29 previous studies on the impact of six explanatory variables on FDI inflows. Although her findings exhibited some deviation from the findings of Chakrabarti, she also posited that factors revolving around regulatory framework are positively significant with inflow of foreign investment. Specifically, trade openness was found to be positively associated with FDI inflows. She observed that the effect of trade openness depended on the type of FDI. Some studies revealed a negative impact of trade openness on marketseeking FDI inflows due to the tariff jumping theory (Anyanwu, 2012) while other studies found that countries that are more opened for international trade receive more FDI inflow (Asiedu, 2002). Alfaro et al.'s (2004) study was focused on financial inducements. In their study, the role of the local financial market was established as a determinant of the absorptive capacity of the southern Africa host countries.

Study by Dupasquier and Osakwe (2006) was centred on infrastructural inducements in Africa. The study showed that FDI in Africa is dependent on the development of infrastructure. A similar study on US FDI flow to Africa by Nnadozie and Osili (2004) found less robust evidence of the role of infrastructure on foreign direct investment inflows. Furthermore, literature (Buckley, 1990; Asheghian, 2004; Peng, 2009) also suggested the influence of favourable investment environments on FDI inflows. According to Aregbesola (2014), this may be in form of favourable interest- and exchange rate differentials for foreign investors (Levi, 
2009; Stiglitz, 2002). In addition, the influence of location advantages was also recognised in the literature as another determinant of FDI inflows. These advantages may arise from differences in a country's natural endowments, transport costs, government regulations, cultural factors and macroeconomic stability (Hill, 2013; Porter, 1990; Schmitz, 2007). According to Dunning (1993) FDI motives may be: (1.) to access labour force, raw materials, and physical resources (2.) to access the host-country domestic market, (3.) to take advantage of lower labour costs, and (4.) to access research and development, innovation, and advanced technology (Anyanwu, 2012; Aizenman and Noy, 2006). Monetary union or integration is also another driver of FDI inflows. This is premised on the ability of a currency union to reduce macroeconomic instability and increase the transparency and credibility of rules and policies (Usman and Ibrahim, 2012). Another benefit of monetary integration is the tendency to reduce trading costs, stabilise exchange rate volatility, trade openness and infrastructural development thereby facilitating foreign direct investment inflows (Asiedu, 2004). In addition, Anyanwu (2012) maintained that the enlarged market as a result of a currency union would also facilitate the exploitation of economies of scale by multinational corporations operating in the host country (Pantelidis, Kyrkilis and Nikolopoulos, 2012; Brouwer, Paap and Viaene, 2008).

\section{Methodology}

This research employed a panel dataset of forty (40) and forty one (41) selected Asian and African countries (see appendix 1 for the list of selected countries) from 1980 to 2013. The other Asian and African countries were eliminated from the analysis because data could not be generated for most of the variables used in the study. The data used in this analysis was generated from the World Trade Organisation (WTO) database, the World Bank's African Development Indicators (ADI), United Nations Commodity Trade Statistics (UNCTS) Database, International Monetary Fund (IMF). Others are United Nations Statistics Database (UNdata), World development indicators ONLINE, and UN Statistics Database (UNdata). Multivariate co integration analysis via granger-causality tests within the framework of Vector Error-correction Model (VECM) was used to analyse the dynamic relationships among the variables (Johansen and Juselius, 1990).

Econometric Model: Baltagi's (2008) criticism of the identification of endogenous and exogenous variables in models of simultaneous equations, paved way for the equal treatment of and no distinction between endogenous and exogenous variables. Once this distinction is ignored, all the variables are treated as endogenous. However, this will lead to the development of the Vector Autoregressive (VAR) models, where all the equations have the same set of regressors (Asteriou and Hall, 2007). VAR model is therefore, important in testing for causality (Correa and Kumar, 2003). Consequently, the model utilised in this study was exclusively adapted from past empirical and theoretical studies (Lee and Tan, 2006). These are represented in the following equations:

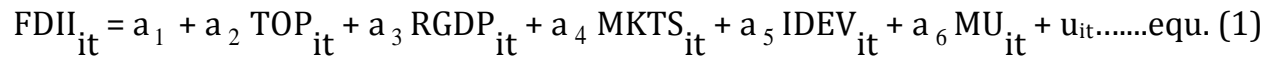

$$
\begin{aligned}
& \text { TOP }_{\text {it }}=b_{1}+b_{2} \text { FDII }_{i t}+b_{3} \text { RGDP }_{i t}+b_{4} \text { MKTS }_{i t}+b_{5} \operatorname{IDEV}_{i t}+b_{6} M U_{i t}+u_{i t} \ldots \text { equ. (2) } \\
& \mathrm{RGDP}_{\text {it }}=\mathrm{c} 1+\mathrm{c}_{2} \mathrm{FDII}_{\mathrm{it}}+\mathrm{c}_{3} \mathrm{TOP}_{\text {it }}+\mathrm{c}_{4} \mathrm{MKTS}_{\text {it }}+\mathrm{c}_{5} \mathrm{IDEV}_{\mathrm{it}}+\mathrm{c}_{6} \mathrm{MU}_{\mathrm{it}}+\mathrm{u}_{\mathrm{it}} \ldots \text { equ. (3) } \\
& \text { MKTS }_{i t}=\mathrm{d}_{1}+\mathrm{d}_{2} \text { FDII }_{\text {it }}+\mathrm{d}_{3} \text { TOP }_{\text {it }}+\mathrm{d}_{4} \mathrm{RGDP}_{\text {it }}+\mathrm{d}_{5} \mathrm{IDEV}_{\text {it }}+\mathrm{d}_{6} \mathrm{MU}_{\mathrm{it}}+\mathrm{u}_{\mathrm{it} \ldots \text { equ. (4) }} \\
& \mathrm{IDEV}_{\text {it }}=\mathrm{e} 1+\mathrm{e}_{2} \mathrm{FDII}_{\text {it }}+\mathrm{e}_{3} \mathrm{TOP}_{\text {it }}+\mathrm{e}_{4} \mathrm{RGDP}_{\text {it }}+\mathrm{e}_{5} \mathrm{MKTS}_{\text {it }}+\mathrm{e}_{6} \mathrm{MU}_{\mathrm{it}}+\mathrm{u}_{\mathrm{it}} \ldots \text { equ. (5) } \\
& \mathrm{MU}_{\text {it }}=\mathrm{f}_{1}+\mathrm{f}_{2} \mathrm{FDII}_{\text {it }}+\mathrm{f}_{3} \mathrm{TOP}_{\text {it }}+\mathrm{f}_{4} \mathrm{RGDP}_{\text {it }}+\mathrm{f}_{5} \mathrm{MKTS}_{\text {it }}+\mathrm{f}_{6} \mathrm{IDEV}_{\text {it }}+\mathrm{u}_{\mathrm{it}} \ldots \text { Equ. (6) } \\
& \text { where: } \\
& \text { FDII = foreign direct investment inflow, which is expressed as a percentage of GDP } \\
& \text { TOP = trade openness, which is measured by merchandise trade to GDP (in percentage) } \\
& \text { RGDP = macroeconomic condition, measured by real GDP growth }
\end{aligned}
$$


MKTS $=$ market size, measured by Population growth

IDEV = infrastructure development

$\mathrm{MU}=$ monetary union dummy

$\mathrm{i}=$ represents the country

$\mathrm{t}=$ represents time

$\mathrm{u}_{\mathrm{it}}=$ the disturbance

The unknown population parameters are represented by a1...a6.

A disturbance is inserted into the models because of the likely omission of explanatory variables, aggregation of variables, model specification, functional misspecification and measurement errors. In addition, it is important to note the following assumptions of the models above: all explanatory variables have values that are fixed in repeated samples, each $\left(\mathrm{u}_{\mathrm{it}}\right)$ disturbance is normally distributed, and there is the non-existence of linear relationships among the values of any two or more of the explanatory variables. That is, perfect multicollinearity is absent (Asteriou and Hall, 2007).

Operationalisation of the Dependent and Explanatory Variables: In focusing this study, the operationalisations of the various determinants (Table 1) were distilled from various articles and empirical research on FDI inflows. They were then categorised into a number of subgroups, similar to the work of Anyanwu (2012). The dependent variable in this research is FDI inflows, proxied by the ratio of FDI flows to GDP. This variable has been used in previous studies (Aregbesola, 2014; Alba, Park \& Wang, 2009; Alfaro et al., 2004; Asiedu, 2002), due to the fact that it accurately captures the relative contribution of FDI to GDP. The independent variables are trade openness, macroeconomic condition, market size, infrastructural development, and monetary union (Anyanwu, 2012; Asheghian, 2004). All the constructs (determinants) and their measures are shown in Table 1.

Table 1: The measure of FDI Determinants (Dependent and Explanatory variable)

\begin{tabular}{|c|c|c|}
\hline Variable & Measure & Author \\
\hline FDII (FDI Inflow) & Expressed as a percentage of GDP & $\begin{array}{l}\text { Alba et al., 2009; Alfaro et al., 2004; } \\
\text { Asiedu, } 2002\end{array}$ \\
\hline TOP (Trade Openness) & $\begin{array}{l}\text { Ratio of merchandise trade to } \\
\text { GDP (in Percentage). }\end{array}$ & $\begin{array}{l}\text { Wheeler and Mody, 1992; Ponce, } \\
\text { 2006; Asiedu, 2002; Anyanwu, } \\
\text { 2012; }\end{array}$ \\
\hline $\begin{array}{l}\text { RGDPG } \quad \text { (macroeconomic } \\
\text { condition) }\end{array}$ & Real GDP growth & $\begin{array}{l}\text { Aregbesola, 2014; Nnadozie and } \\
\text { Osili, 2004. }\end{array}$ \\
\hline MKTS (Market size) & Population growth & $\begin{array}{l}\text { Anyanwu, 1998, 2011, 2012; } \\
\text { Kyereboah-Coleman and Agyire- } \\
\text { Tettey, } 2008\end{array}$ \\
\hline $\begin{array}{ll}\text { IDEV } & \text { (Infrastructure } \\
\text { Development) }\end{array}$ & Infrastructure development & $\begin{array}{l}\text { Dupasquier and Osakwe, 2006; } \\
\text { Nnadozie and Osili, } 2004\end{array}$ \\
\hline MU (Monetary Union) & $\begin{array}{l}\text { A dummy variable of ' } 1 \text { 'if a } \\
\text { country is a member of monetary } \\
\text { or currency union. Another } \\
\text { dummy of ' } 0 \text { ' if otherwise }\end{array}$ & $\begin{array}{lcr}\text { Usman and } & \text { Ibrahim, } & 2012 ; \\
\text { Pantelidis, } & \text { Kyrkilis } & \text { and } \\
\text { Nikolopoulos, } 2012 & \end{array}$ \\
\hline
\end{tabular}

In this study, economic openness is proxied by the ratio of merchandise trade to GDP. Macroeconomic condition was measured by real GDP growth, on the premise that a country with perceived stable macroeconomic fundamentals is adjudged a stable investment environment (Aregbesola, 2014; Nnadozie and Osili, 2004). In addition, population growth was introduced because this variable is considered an important determinant of market size, especially if the population growth is accompanied by a rise in income level or potential improvement in the standard of living (Anyanwu, 2011, 2012). Infrastructure development was also introduced due to the influence of the various aspects of infrastructural facilities such as roads, electricity, transportation, insurance, banking and finance on FDI inflows (Dupasquier and Osakwe, 2006; Nnadozie and Osili, 2004). Lastly, monetary union is proxied by a dummy, monetary integration, which assumes the value of 1 if a country is a member of a Monetary Union, but $=0$ if otherwise (Anyanwu, 2012) 


\section{Results and Discussion of Findings}

Descriptive Statistics: This study used Granger causality test, under vector error correction modelling (VECM) to test for causality among the panel variables. However, before the application of these techniques, a series of diagnostic tests were undertaken to cater for sensitivity and reliability (Hailu, 2010; Kimura and Todo, 2010). Redundant variables were also eliminated, while provision was made for the possibility of omitted variables. Initially, the Hausman test was conducted (Dupasquier and Osakwe, 2006; Aseidu, 2002) to control for autocorrelation. Standard errors were catered for via White diagonal standard errors and covariance technique (Aregbesola, 2014). Table 2 shows the correlation matrix of all the variables (except the Dummy Variable). Significantly, none of the explanatory variables were strongly correlated. Consequently, all the variables were used in our analysis. These results were robust and show the absence of arbitrary serial correlation and time varying variances in the disturbances.

Table 2: Descriptive Statistics and Correlations of all Regression Variables (excluding Dummies) from 1980-2013

\begin{tabular}{lllllllll}
\hline Constructs (Asia: Panel A) & Obs. & Mean & S.D & $\mathbf{1}$ & $\mathbf{2}$ & $\mathbf{3}$ & $\mathbf{4}$ & $\mathbf{5}$ \\
\hline LnFDII & 585 & 1.21 & 0.89 & 1.00 & & & & \\
LnTOP & 509 & 2.63 & 1.47 & $0.19^{*}$ & 1.00 & & & \\
LnRGDP & 575 & 3.24 & 1.47 & $0.24^{* *}$ & $0.18^{*}$ & 1.00 & & \\
LnMKTS & 538 & 4.34 & 1.43 & $0.23^{* *}$ & $0.24^{* *}$ & 0.09 & 1.00 & \\
LnIDEV & 507 & 3.51 & 0.54 & 0.10 & $0.25^{* *}$ & $0.21^{* *}$ & $0.22^{*}$ & 1.00 \\
Constructs (Africa: Panel B) & Obs. & Mean & S.D & 1 & 2 & 3 & 4 & 5 \\
LnFDII & 562 & 3.22 & 1.48 & 1.00 & & & & \\
LnTOP & 525 & 2.61 & 1.02 & 0.13 & 1.00 & & & \\
LnRGDP & 560 & 3.25 & 1.10 & $0.21^{* *}$ & $0.21^{* *}$ & 1.00 & & \\
LnMKTS & 522 & 4.34 & 0.48 & 0.11 & $0.24^{* *}$ & $0.31^{* *}$ & 1.00 & \\
LnIDEV & 501 & 3.51 & 0.51 & $-0.23^{*}$ & $0.21^{* *}$ & 0.09 & 0.11 & 1.00 \\
\hline
\end{tabular}

Note: ${ }^{*} \mathrm{p} \leq 0.1,{ }^{* *} \mathrm{p} \leq 0.05,{ }^{* * *} \mathrm{p} \leq 0.001$

Secondly, in order to determine the order of integration, a unit root test was conducted. This was an attempt to identify non-stationarity (unit roots).

Unit Root Test: The standard Augmented Dickey-Fuller (ADF) test was conducted to eliminate autocorrelation and whiten noise (Anyanwu, 2012). Phillips Perron (PP) test was also conducted given the imperative of uncorrelated error terms (Asteriou and Hall, 2007). These tests are important since the data used in this study, as is frequently the case with macroeconomic time series, are often trended and nonstationary. According to Blaise (2005) a regression of one series on the other is most likely an indication that a significant positive or negative relationship would result; even though they are really unrelated. This is the concept of spurious regression, hence, a violation of the Classical Linear Regression Model (CLRM) (Fedderke and Romm, 2006; Asteriou and Hall, 2007). The ADF test was also performed to take care of structural breaks, since country-specific conditioning variables can be permanently altered by major shocks (Harms and Lutz, 2006). In addition, the unit root test is also a precursor for the Granger Causality test, as adopted in this study. The Granger Causality test is based on the asymptotic theory, which prescribes the stationarity of variables in the same order of integration (Granger, 1988). The two tests were conducted at the level, first difference and second difference series (Hair et al., 1998). The results of the unit root tests are presented in Table 3. 
Table 3: Results of Unit Root Tests

\begin{tabular}{|c|c|c|c|c|c|}
\hline \multirow[t]{2}{*}{ Variables } & \multicolumn{2}{|l|}{ ADF Test: } & \multicolumn{2}{|l|}{ PP Test: } & \multirow{2}{*}{$\begin{array}{l}\text { Order of } \\
\text { Integration }\end{array}$} \\
\hline & $\begin{array}{l}\text { First } \\
\text { Difference: } \\
\text { Constant } \\
\text { with Trend }\end{array}$ & $2^{\text {nd }}$ Diff. Statistics & $\begin{array}{l}\text { First } \\
\text { Difference: } \\
\text { Constant } \\
\text { with Trend }\end{array}$ & $\begin{array}{l}2^{\text {nd }} \quad \text { Diff. } \\
\text { Statistics }\end{array}$ & \\
\hline \multicolumn{6}{|l|}{ Asia (Panel } \\
\hline A) & $-5.332540 * *$ & -6.273847 & $-5.234606^{*}$ & -4.237646 & $1(2)$ \\
\hline LnTOP & $-3.322673^{*}$ & -3.842837 & $-4.234134^{* *}$ & -3.692837 & $1(2)$ \\
\hline LnRGDP & $-4.027389 *$ & -4.429874 & $-3.236805^{*}$ & -4.583837 & $1(2)$ \\
\hline LnMKTS & $-2.347831 * *$ & -3.237845 & $-2.173741^{* * *}$ & -5.239946 & $1(2)$ \\
\hline LnIDEV & $-2.734534^{*}$ & -2.293494 & $-1.746836^{*}$ & -2.838374 & $1(2)$ \\
\hline \multicolumn{6}{|l|}{ LnMU } \\
\hline \multicolumn{6}{|l|}{$\underline{\text { Africa }}$} \\
\hline (Panel B) & $-5.273640 *$ & -5.423839 & $-6.387374 * *$ & -6.476575 & $1(2)$ \\
\hline LnTOP & $-3.278346^{* *}$ & -4.838398 & $-3.128842^{* *}$ & -5.384748 & $1(2)$ \\
\hline LnRGDP & $-3.092839 * *$ & -3.883743 & $-4.447847^{* *}$ & -3.283735 & $1(2)$ \\
\hline LnMKTS & $-4.237458^{*}$ & -3.283974 & $-4.384741^{*}$ & -3.384748 & $1(2)$ \\
\hline $\begin{array}{l}\text { LnIDEV } \\
\end{array}$ & $-2.273844^{*}$ & -2.233647 & $-2.364767^{*}$ & -2.857587 & $1(2)$ \\
\hline
\end{tabular}

Note: ${ }^{*}, * *$ and ${ }^{* * *}$ implies $1 \%, 5 \%$ and $10 \%$ levels of significant respectively

The result of the unit root test assumed stationarity of the series for all the variables by the rejection of the null hypothesis for second difference at all the critical values (maximum lag of one). Therefore, the models follow an integrating order of 1(2) process and are therefore a stationary process (Kok and Ersoy, 2009). The computed value of the test statistic was also compared to the critical value for both the ADF and PP test (constant with trend) in order to reject or accept the null hypothesis. Consequently, a null hypothesis was rejected, since the former was greater (in absolute value) than the latter (Hair et al., 1998).

Granger Causality Test, under VECM: Cointegration was tested using the Johansen approach. An approach referred to as reduced-rank regression methodology was employed (Levin, Lin, and Chu, 2002). Step one was to determine the order of integration. This was done by testing for unit-roots to determine the level of co integration and the appropriate models were selected using the Mohamed and Sidiropoulos (2010) criterion. The second step was to determine the optimal lag length. This was estimated for a low number of lags and then reduces down to check for the AIC and SBC optimal value (Asteriou and Hall, 2007). It is also important to note that diagnostics methodology often reduces the number of panel units in the estimation and as such, influences the explanatory power of the model. According to Aregbesola (2014) this justifies the application of the orthogonal deviation technique, which is more efficient than differencing the panel data. However, cointegration only indicates the presence or absence of Granger-causality, and it often failed in any way show the route of causality hence, this route was decided via VECM (Oladipo, 2008). This research, however, used Granger causality test (modified by Pantelidis and Nikopoulos, 2008) under VECM to test for causality among the variables. In this study, the null hypothesis of causality test holds if the probability statistics do not fall within the range of 0.01 or 0.10 , and vice versa. The results of this analysis are reported in Tables 4 and 5 for the two panels, Asia (Panel A) and Africa (Panel B) respectively. From Tables 4 and 5 respectively, the Sargan tests (0.2633 and 0.2132) negates the over identifying restrictions (Asteriou and Hall, 2007). Furthermore, as a diagnostic measure, Durbin-Watson statistics of 2.122 and 2.091, respectively for the two panels posits the absence of potential first order autocorrelation in all the variables. The results of VECM in Table 4, therefore, suggests that apart from market size (population growth; 1.23133, $\mathrm{p}=0.1723$ ),all the variables tested in this study are regarded as important considerations for attracting FDI to Asian economies. Specifically, in order of importance, macroeconomic condition, trade openness, monetary union, and infrastructural 
Table 4: VECM Results for Asian Panel ( $p=2)$

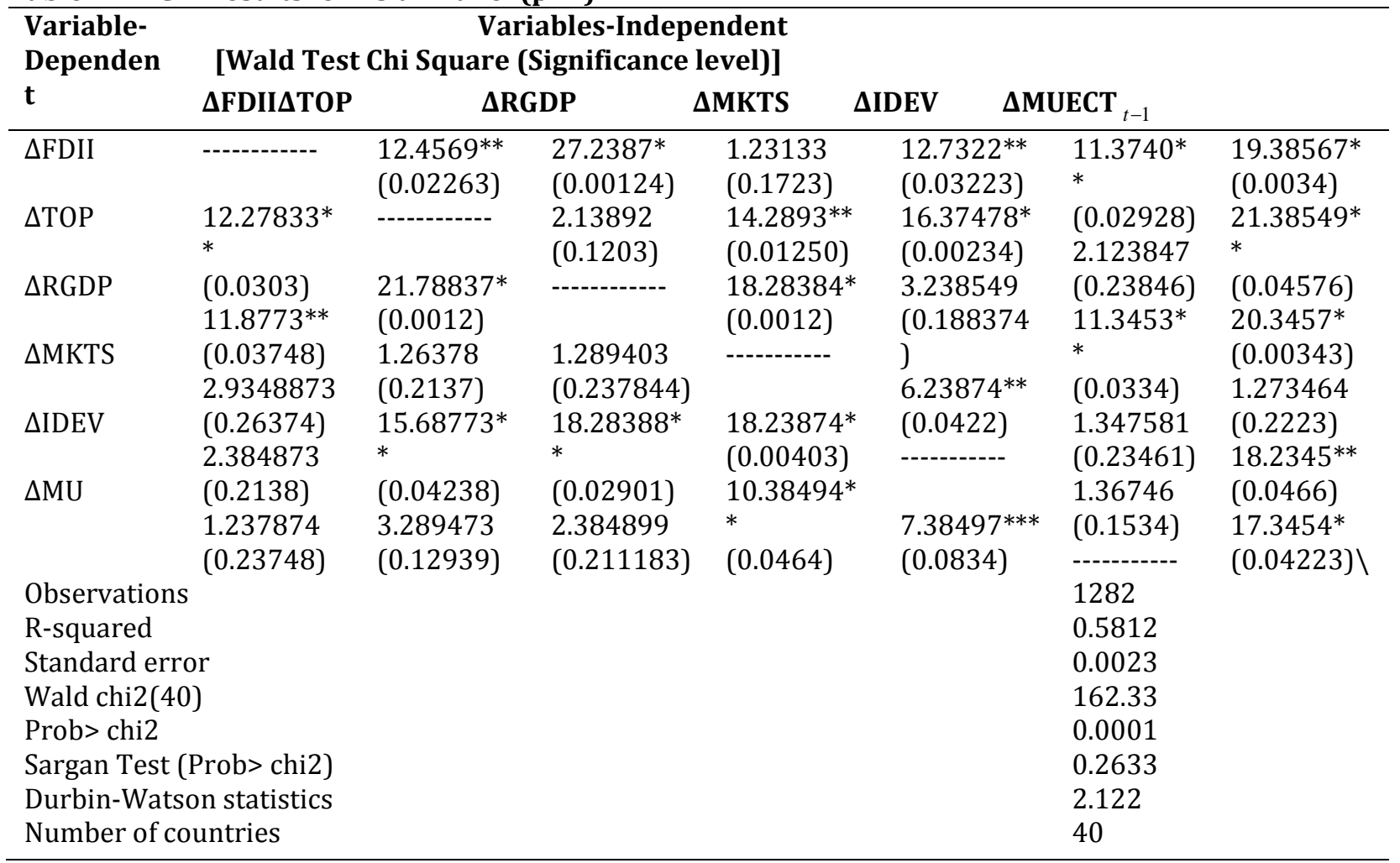

Note: ${ }^{*}, *$ and ${ }^{* * *}$ indicate statistical significant at $1 \%, 5 \%$ and $10 \%$

Table 5: VECM Results for African Panel $(p=2)$

\begin{tabular}{|c|c|c|c|c|c|c|c|}
\hline \multirow[t]{2}{*}{$\begin{array}{l}\text { Variable- } \\
\text { Dependent }\end{array}$} & \multicolumn{4}{|c|}{$\begin{array}{c}\text { Variables-Independent } \\
\text { [Wald Test Chi Square (Significance level)] }\end{array}$} & & & \\
\hline & \multicolumn{2}{|c|}{$\Delta$ FDII $\Delta$ TOP $\Delta R G D P$} & \multicolumn{5}{|c|}{ 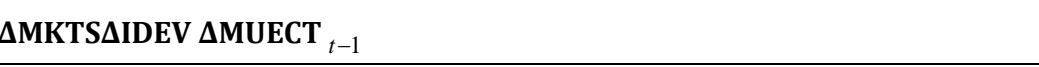 } \\
\hline$\Delta \mathrm{FDII}$ & ---- & $\begin{array}{l}9.26763^{* * *} \\
(0.06875)\end{array}$ & $\begin{array}{l}21.27735^{*} \\
(0.004334)\end{array}$ & $\begin{array}{l}28.7271^{*} \\
(0.00246)\end{array}$ & $\begin{array}{l}20.272867^{*} \\
(0.00535)\end{array}$ & $\begin{array}{l}2.27377 \\
(0.299387)\end{array}$ & $\begin{array}{l}23.2736^{*} \\
(0.00222)\end{array}$ \\
\hline$\triangle \mathrm{TOP}$ & $\begin{array}{l}12.876339^{* *} \\
(0.0423)\end{array}$ & - & $\begin{array}{l}2.83784 \\
(0.23334)\end{array}$ & $\begin{array}{l}16.2838^{*} \\
(0.00346)\end{array}$ & $\begin{array}{l}1.28373 \\
(0.2230)\end{array}$ & $\begin{array}{l}3.363737 \\
(0.2332)\end{array}$ & $\begin{array}{l}20.2828^{*} \\
(0.002331)\end{array}$ \\
\hline$\Delta \mathrm{RGDP}$ & $\begin{array}{l}21.28372^{*} \\
(0.00384)\end{array}$ & $\begin{array}{l}7.27378^{* * *} \\
(0.0689)\end{array}$ & ------- & $\begin{array}{l}2.73833 \\
(0.1253)\end{array}$ & $\begin{array}{l}9.28383^{* *} \\
(0.03111)\end{array}$ & $\begin{array}{l}13.3748^{* *} \\
(0.04556)\end{array}$ & $\begin{array}{l}13.2838^{* *} \\
(0.0456)\end{array}$ \\
\hline$\Delta \mathrm{MKTS}$ & $\begin{array}{l}16.7378^{*} \\
(0.00234)\end{array}$ & $\begin{array}{l}1.272883 \\
(0.2366)\end{array}$ & $\begin{array}{l}10.92728^{* *} \\
(0.0337)\end{array}$ & --.-- & $\begin{array}{l}21.28288^{*} \\
(0.00235)\end{array}$ & $\begin{array}{l}1.28383 \\
(0.1439)\end{array}$ & $\begin{array}{l}11.73736^{* *} \\
(0.0421)\end{array}$ \\
\hline$\triangle \mathrm{IDEV}$ & $\begin{array}{l}2.83782 \\
(0.4333)\end{array}$ & $\begin{array}{l}11.283783^{* *} \\
(0.0290)\end{array}$ & $\begin{array}{l}3.73637 \\
(0.13784)\end{array}$ & $\begin{array}{l}2.2838 \\
(0.1201)\end{array}$ & ------ & $\begin{array}{l}12.26387^{* *} \\
(0.0393)\end{array}$ & $\begin{array}{l}23.83672^{*} \\
(0.002671)\end{array}$ \\
\hline$\Delta \mathrm{MU}$ & $\begin{array}{l}2.2838737 \\
(0.2738)\end{array}$ & $\begin{array}{l}2.572878 \\
(0.14146)\end{array}$ & $\begin{array}{l}3.2938783 \\
(0.33782)\end{array}$ & $\begin{array}{l}1.84781 \\
(0.1346)\end{array}$ & $\begin{array}{l}3.267362 \\
(0.2387)\end{array}$ & ------ & $\begin{array}{l}2.273733 \\
(0.32891)\end{array}$ \\
\hline Observations & & & & & & 1267 & \\
\hline R-squared & & & & & & 0.5123 & \\
\hline Standard err & & & & & & 0.0022 & \\
\hline Wald chi2(4) & & & & & & 166.21 & \\
\hline Prob> chi2 & & & & & & 0.0004 & \\
\hline Sargan Test & Prob> chi2) & & & & & 0.2132 & \\
\hline Durbin-Wats & n statistics & & & & & 2.091 & \\
\hline Number of ce & untries & & & & & 41 & \\
\hline
\end{tabular}

Note: ${ }^{*}{ }^{* *}$ and ${ }^{* * *}$ indicate statistical significant at $1 \%, 5 \%$ and $10 \%$ 
Development is statistically significant at $1 \%, 5 \%, 5 \%$ and $5 \%$ levels respectively. On the other hand, the results of VECM in Table 5, also suggest that apart from monetary union (2.27377, $\mathrm{p}=0.299387$ ), all the variables tested in the model are regarded as important considerations for inward FDI to African economies. Specifically, in order of importance, market size (population size), macroeconomic condition, infrastructural development, and trade openness are statistically significant at $1 \%, 1 \%, 1 \%$ and $10 \%$ levels respectively.

Asian panel (A) and African panel (B) consists of three and four co-integrating vectors respectively, consequently, a Wald test was carried out on each of the error correction terms (Tsai, 1994). This simply denotes that three and four (regulatory and non-regulatory) variables are interacted (in pairs) to investigate the explosive nature of the estimations. The robust standard errors (0.0023 and 0.0022) and the p-value of the estimation (0.0001 and 0.0004) attest to the statistical significance of the results for the two continents respectively (Aregbesola, 2014).The Granger-causality result for Asian and African panels are shown in Tables 4 and 5 respectively. The Wald test Chi Square result, for the two continents showed a causal effect both running bi-directionally and uni-directionally for the two panels. For clarity of purpose, the lead-lag linkages for each continent are shown in Figures 1 ( $a$ and $b$ ).

\section{Figure 1: Lead-lag Linkages in the Short Run from VECMs}
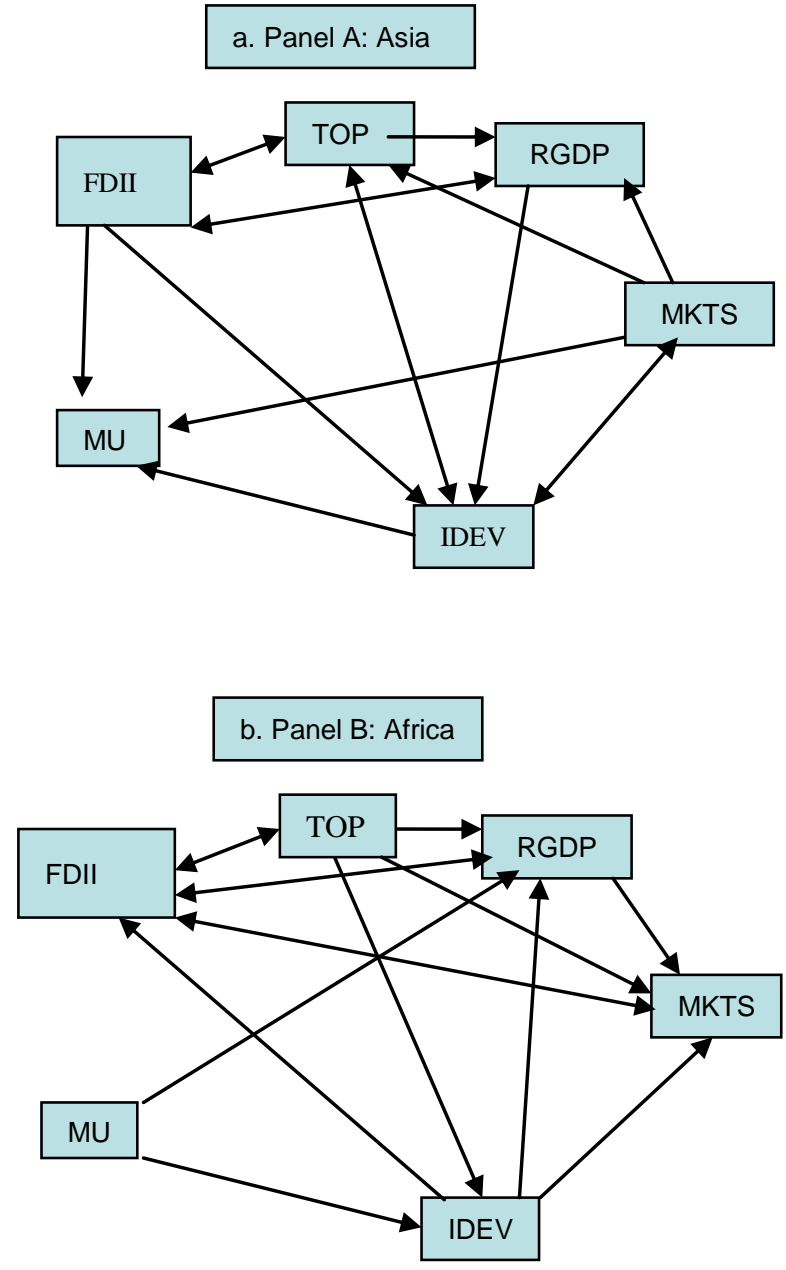

Discussion of Findings: In Figure 1a, this study found bi-directional causal relationships between FDII and both TOP and RGDP in Asia. In addition, TOP and IDEV also experienced a bi-directional causal relationship during the study period. This simply implied that, while trade openness and macroeconomic condition positively contributed to FDI inflows to Asia, improved FDI inflow also contributed positively to both trade 
openness and real GDP growth during the study period. Furthermore, in Figure 1b, the study also found a bidirectional causal relationship between FDII and TOP, RGDP and MKTS in Africa during the study period. This also implied that, while trade openness, macroeconomic condition and market size positively contributed to FDI inflows to Africa, improved FDI inflow also positively contributed toward improvements in trade openness, real GDP growth (macroeconomic condition) and population growth (market size) during the study period. These results are similar to previous studies (Nnadozie and Osili, 2004; Dupasquier and Osakwe, 2006; Asiedu, 2002; Ashegian 2004; Akinkugbe, 2005; Caves, 2007). For example, economic openness was found by Asiedu (2002)to have a direct causal relationship with inflow of FDI. This further buttresses the possible impact of economic liberalisation as an important determinant of the attractiveness of both Asia and Africa to inflow of FDI (Aregbesola, 2014). In addition, the reverse causality between inflow of FDI and population growth in Africa may imply that an increase in inflow of FDI may precipitate population growth (Akinkugbe, 2005). Logically, an increase in income level and standard of living due to increased inflow of FDI may result in creating a larger consumer market size (Ashegian 2004; Caves, 2007). However, some studies cautioned about the effect of trade openness on the type of FDI while others found a negative impact of trade openness on market-seeking FDI inflows, due to what is referred to as tariff jumping theory effect (Anyanwu, 2012).

In terms of the influence of real GDP growth on FDI inflows, this study concurs with the submissions of Nnadozie and Osili (2004) which found less evidence of the role of GDP per capita on FDI inflow, while GDP growth is found to have significant impact. Furthermore, Lee and Tan's (2006) study on a few selected ASEAN countries concluded that increasing GDP and regulatory environments actually influenced the level of FDI flows to this region. This finding is similar to that of Yasin (2005) in terms of economic growth and FDI linkages from developed countries. On the contrary, other studies have concluded that macroeconomic condition, namely, poor governance and inhospitable regulatory environments (foreign ownership ceiling; policy on repatriation of capital and remittance of profit; and government regulations and restrictions on equity holdings) were found to have a negative impact on FDI inflow (Nnadozie and Osili, 2004; Dupasquier and Osakwe, 2006). The role of market size as driver of FDI inflow was mixed in this study. While market size (population growth) was found to be statistically significant with FDI inflow to African countries, the reverse was the case in Asia during the study period. This scenario is akin to the conclusions of Anyanwu (1998, 2011, 2012) and Kyereboah-Coleman and Agyire-Tettey (2008). While maintaining the important role of market size in influencing FDI inflows (Anyanwu, 1998, 2011, 2012), the results of Kyereboah-Coleman and Agyire-Tettey (2008) indicated that most foreign investors do not consider this factor in making a decision to invest in Ghana. Furthermore, this study also concurs with the findings of Dupasquier and Osakwe (2006) which showed that FDI in Africa is dependent on the development of infrastructure. However, the results of a similar study on US FDI flow to Africa by Nnadozie and Osili (2004) found less robust evidence on the role of infrastructure on FDI inflows. Findings by Sekkat and Veganzones-Varoudakis (2007) also indicated that infrastructure availability, openness, and sound economic and political conditions are important for South Asia, Africa, and the Middle East in attracting FDI.

A key novel finding in this paper was the mixed results on the influence of monetary union on FDI inflow to the two continents. It should be noted that, unlike the influence in Asia, monetary union was not as effective in Africa during the study period. In fact, none of the variables contributed towards the advancement of monetary union in Africa, while monetary unions, on the other hand, only managed to influence population growth and improvement in infrastructural development. This result might not be unconnected with the level of monetary union or integration in the Asia Pacific region, compared with the African region. Consequently, the benefits of monetary integration, namely are duction in trading costs, the elimination of exchange rate volatility, and the reduction of future competitive devaluation may facilitate the inflow of foreign direct investment. The enlarged market as a result of currency union may also encourage economies of scale by MNCs (Pantelidis, Kyrkilis and Nikolopoulos, 2012).

\section{Conclusion and Implications of the Study}

Unlike earlier studies based on developed and emerging economies (and only a few concentrated on a comparative analysis of vast African and Asian countries), this paper analysed the determinants of foreign direct investments (FDI) inflow to Asian and African economies using a panel dataset from 1980 to 2013. This 
study used Granger causality test, under vector error correction modelling (VECM) to test for causality among the variables. Findings based on the study revealed that variables manifesting the determinants of FDI inflows positively affected FDI into these continents. Specifically, trade openness, macroeconomic condition, infrastructural development, and monetary union have positive and significant effects on FDI inflows to Asian economies while there is no significant relationship between FDI inflows and market size on the continent during the study period. On the other hand, trade openness, macroeconomic condition, market size and infrastructural development have positive and significant effects on FDI inflows to African economies while there is no significant relationship between FDI inflows and monetary union on the African continent during the study period. These results are similar to previous studies (Nnadozie and Osili, 2004; Dupasquier and Osakwe, 2006; Asiedu, 2002; Ashegian 2004; Akinkugbe, 2005; Caves, 2007). In addition, there was a bidirectional relationship between FDI inflows and some of the variables in the model of both continents. For example, the study found bi-directional causal relationships between FDII and both TOP and RGDP in Asia. In addition, TOP and IDEV also experienced another bi-directional causal relationship during the study period. This simply implied that while trade openness and macroeconomic condition positively contributed to FDI inflows to Asia, improved FDI inflow also contributed positively to both trade openness and real GDP growth during the study period. In the African model, the study found a bi-directional causal relationship between FDII and TOP, RGDP and MKTS. This also implied that, while trade openness, macroeconomic condition and market size positively contributed to FDI inflows to Africa, improved FDI inflow also positively contributed toward improvements in trade openness, real GDP growth, and population growth. However, a key novel finding in this paper was the mixed results in terms of the influence of monetary union on FDI inflow to the two continents. These offered various theoretical and empirical implications.

Theoretical and Empirical Implications: Theoretically, this model provides predictive implications on improved FDI inflows, given the activities of critical variables manifesting determinants of FDI inflows. According to UNCTAD (2014) the increased FDI inflow to Africa in 2013 was driven by international and regional market-seeking investments as well as infrastructure investments. This concurs with the location specific advantage of Dunning's (1981) Eclectic theory which was used as the theoretical framework for this study. The theory suggests the importance of firm- and location-specific factors to explain the determinants of FDI inflows. The location-specific advantages in this scenario are the available markets for both inputs and finished products; resources in terms of raw materials; availability of human capital; or a favourable political economy (Dunning, 1981; Aregbesola, 2014). Furthermore, policy makers in both developing and emerging economies should be interested in the findings of this study, since the results have highlighted some of the benefits, linkages and relationships among FDI inflows and its various determinants. This may therefore give policy makers working at government agencies or trade representative's office some helpful information to bring to the negotiating table. Although the Asia region is becoming increasingly attractive to FDI, liberalisation of FDI policies is essential for attracting further inflows. In addition, policy makers need to remain vigilant and keep the reform momentum going forward rather than sliding backwards, particularly in the current context of the South Asia's economic slowdown. In Africa, the positive and significant relationship between real GDP growth and population growth should be sustained. This was, however, boosted by the recent UNCTAD report. Specifically, UNCTAD (2014) posit for the continuation of a sustained economic and population growth in Africa to attract market-seeking FDI into consumer-oriented industries. There is an urgent need to strengthen intra-regional investments, since most of the outflows were directed to other countries in the continent, paving the way for investment-driven regional integration.

Although, this study found a bi-directional causal relationship between FDI inflow and trade openness in Asia, openness to FDI has historically been far from uniform across Asia. While China and the Association of Southeast Asian Nations (ASEAN) have embraced FDI, other economies have been comparatively unreceptive. In addition, regional powerhouses such as India, South Korea and Japan have been hesitant to open themselves fully to FDI inflow (Anyanwu, 2012; Pantelidis et al., 2012; Reiter et al., 2010). Consequently, as the global economy begins to slow again, a number of the regions largest economies must formulate policies that will make them becoming more receptive to the possibilities of FDI (Aregbesola, 2014; UNCTAD, 2015). On the other hand, for African economies to counter the impact of the declining commodities and crude oil prices. Despite the considerable investment from foreign transnational corporations (TNCs) in 2013 in Ghana, Gabon and Côte d'Ivoire, there is need to develop a favorable business hub, not only for oil and gas exploration in the sub region, but also in industrial production and transport services. There is also the need 
for other African countries to emulate Ethiopia's industrial strategy which focuses on attracting capital induced FDI inflows to develop their manufacturing base. Looking forward to the sustainable development goals (SDGs) that will succeed the Millennium Development Goals, for Asian countries to improve on the current tempo of FDI inflow, the stable performance of East Asia (rose by 3 per cent to $\$ 221$ billion in 2013) must be utilized as a strategic imperative to counter slower growth in South-East Asia (Aregbesola, 2014). This study also recognized the influence of macroeconomic condition as a veritable driver of FDI inflow to Asia. Unlike many African countries, some Asian countries have utilized both monetary and non-monetary incentives effectively to encourage FDI. Malaysia, for example, has been offering incentives such as tax holidays of up to 10years with pioneer status; an investment tax allowance; a reinvestment allowance; and special deductions for training in the last two decades (UNCTAD, 2014; Lee and Tan, 2006). Singapore's government also provides many competitive direct and indirect incentives for FDI in targeted sectors. That notwithstanding, effort should be made to eliminate the seemingly macroeconomic uncertainties in India. Improvements in FDI inflow to Bangladesh should also be complemented by strengthening the reforms in the manufacturing sector to be able to contribute significantly to employment creation (UNCTAD, 2015). There is an urgent need to sustain the robust economic growth, while new liberalization measures, such as the launch of the China (Shanghai) Pilot Free Trade Zone, East Asia (Aregbesola, 2014; UNCTAD, 2015) are put in place.

Although the influence of monetary union on FDI inflow to Asia was significant in this study, further reforms are needed to bring about the much desired benefits of monetary integration, namely the reduction in trading costs; elimination of exchange rate volatility; and reduction of future competitive devaluation. These may facilitate the inflow of foreign direct investment (Pantelidis, Kyrkilis and Nikolopoulos, 2012). This was also corroborated by the recent UNCTAD report. According to UNCTAD (2014), although Asia tops the world in foreign direct investment, better regional integration and connectivity would boost further FDI flows and prompt development. There is also the need to sustain the 2013FDI inflows to South Asia (which rose by 10 per cent to $\$ 36$ billion) by vigorously pursuing the sub regional cross-border M\&A. Attempts should be made to forestall the declining level of Greenfield investments in the region (UNCTAD, 2015). Although many reforms have been mooted to achieve these objectives, it is the view of this study that a region-wide reduction of FDI barriers has the potential to be one of the most transformative of all the reforms. The insignificant relationship between monetary union and FDI inflow into Africa during the study period might not be unconnected with inactivity of monetary or trade union in the continent. Specifically, UNCTAD (2014) observed that only in two regional economic cooperation (REC) initiatives does intra-group FDI make up a significant part of intra-African investments (in the East African Community-EAC, and the South African Development Community-SADC). Consequently, there is a need to strengthen the existing monetary union in Africa. This is on the premise that a monetary union can contribute to the build-up of regional value chains through intra-regional investments (Akinkugbe, 2005; Caves, 2007). Because an increasing part of value added in trade consists of services, FDI in services is important in supporting the participation of African economies in global value chains. It is also important in the context of financing progress towards the sustainable development goals (UNCTAD, 2015).

Regarding the influence of infrastructural development, UNCTAD's report highlighted the influence of weak infrastructure in some low-income countries in developing Asia. Specifically, UNCTAD (2015) challenged the rising intra-regional FDI in infrastructure industries, driven by regional integration efforts and enhanced connectivity between sub regions, as a catalyst to accelerate infrastructural build-up and promote economic development. In addition, the potential establishment of the Bangladesh-China-India-Myanmar Economic Corridor and the China-Pakistan Economic Corridor are likely to accelerate infrastructural development by attracting foreign investment in related countries (UNCTAD, 2015). The significant influence of infrastructural development was also evidenced in Southern Africa inflows of $\$ 13$ billion in 2013, mainly due to record-high flows into South Africa and Mozambique, where infrastructure was the main attraction (Aregbesola, 2014; UNCTAD, 2014). Intra-African investments also need to be increased. This should be led by South African, Kenyan, and Nigerian TNCs. This is on the premise that intraregional FDI could serve as a significant source of foreign capital for many smaller, often landlocked or non-oil-exporting countries in Africa. However, the results of this study should be adopted with care. Since our findings only indicate the Granger-exogeneity of the dependent variable within the sample period, they do not provide information regarding the relative strength of the Granger-causal chain among the variables outside the sample period (Asiedu, 2006; Lee and Tan, 2006). In addition, it could be argued that grouping some determinants that have 
been identified in the literature as prerequisites to improved inflow of FDI in one set and treating them equally may be misleading because they are not of equal importance. Another limitation was the not availability of data in many developing countries, and even when available, they are often distorted. This may be due to the level of poverty, corruption, illiteracy and inability of the relevant government agencies to collect and update data. Consequently, the main "inevitable" weakness of our regression results was the specifications used to measure the determinants of FDI inflow, which do not include a number of other relevant variables. Further studies might consider the inclusion of these variables; chiefly among the variable are institutional quality, resource endowments, agglomeration effects and the degree of diversification of the economy (Anyanwu \& Yameogo, 2015; El-Wassal, 2012).

Acknowledgements: The first author appreciates the postdoctoral research grant provided by the Graduate School of Business and Leadership, University of KwaZulu-Natal, South Africa. We also acknowledge the valuable comments of two anonymous reviewers and David Barraclough for editing the earlier version of this paper.

\section{References}

Adam, A. N. \& Tweneboah, G. (2009). Foreign Direct Investment and Stock Market Development: Ghana's Evidence. International Research Journal of Finance and Economics, 26 (2), 178-85.

African Development Bank. (2012). African Development Report 2012. African Development Bank. Tunis

Aizenman, J. \& Noy, I. (2006). FDI and Trade-Two-Way Linkages? Quarterly Review of Economics and Finance, 46 (3), 317-37.

Akinkugbe, O. (2005). A Two-part econometric analysis of foreign direct investment flows to Africa. Netherlands: Kluwer Law International.

Alba, J. D., Park, D. \& Wang, P. (2009). The impact of exchange rate on FDI and the interdependence of FDI over time. ADB Economics Working Paper Series, 164.

Alfaro, L., Chanda, A., Kalemli-Ozcan, S. \& Sayek, S. (2004). FDI and Economic Growth: The Role of Local Financial Markets. Journal of International Economics, 64(1), 89-112.

Al-Sadig, A. (2009). The Effects of Corruption on FDI Inflows. Cato Journal, 29(2), 23-31.

Alsan, M., Bloom, D. E. \& Canning, D. (2006). The Effect of Population Health on Foreign Direct Investment Inflows to Low- and Middle-Income Countries. World Development, 34(4), 613-630.

Anyanwu, J. C. (1998). An Econometric Investigation of the Determinants of Foreign Investment in Nigeria, in Nigerian Economic Society (1998). Rekindling Investment for Economic Development in Nigeria, Ibadan, 219 - 241

Anyanwu, J. C. \& Erhijakpor, A. E. O. (2004). Trends and Determinants of Foreign Direct Investment in Africa. West African Journal of Monetary and Economic Integration, 2(2), 21-44.

Anyanwu, J. C. (2006). Promoting of Investment in Africa. African Development Review, 18(1), 42-71.

Anyanwu, J. C. (2011). Determinants of Foreign Direct Investment Inflows to Africa, 1980-2007, Working Paper No. 136, African Development Bank, Tunis.

Anyanwu, J. C. (2012). Why Does Foreign Direct Investment Go Where It Goes? New Evidence from African Countries. Annals of Economics and Finance, 13(2), 433-470.

Anyanwu, J. C. \& Yameogo, N. D. (2015). What Drives Foreign Direct Investments into West Africa? An Empirical Investigation. African Development Review, 27(3), 199-215

Aregbesola, A. R. (2014). Foreign Direct Investment and Institutional Adequacy: New Granger Causality Evidence from African Countries. South African Journal of Economic and Management Sciences, 17(5), 557-568

Asheghian, P. (2004). Determinants of Economic Growth in the United States: The Role of Foreign Direct Investment. The International Trade Journal, 18(1), 63-83.

Asiedu, E. (2004). Capital Controls and Foreign Direct Investment. World Development, 32(3), 479-490.

Asiedu, E. (2002). On the Determinant of Foreign Direct Investment to Developing Countries: Is Africa Different? World Development, 30(1), 107-19.

Asiedu, E. (2006). Foreign Direct Investment in Africa: The Role of Natural Resources, Market Size, Government Policy, Institutions and Political Instability. World Economy, 29(3), 63-77.

Asteriou, D. \& Hall, S. G. (2007). Applied Econometrics: A Modern approach. (Revised Edition).NY: Palmgrave Macmillan 
Awan, A. G. (2013). Diverging trends of human capital in BRICS countries. International Journal of Asian Social Science, 2(12), 2195-2219.

Baltagi, B. H. (2008). Econometrics analysis of panel data (4th Ed.) Chichester: John Wiley and Sons Ltd.

Barro, R. \& Sala-I-Martin, X. (1995). Economic growth. New York: McGraw-Hill.

Billington, N. M. (1999). The Location of Foreign Direct Investment: An Empirical Analysis. Journal of Applied Economics, 31(3), 65-76.

Blaise, S. (2005). On the Link between Japanese ODA and FDI in China: A Micro Economic Evaluation using Conditional Logit Analysis. Applied Economics, 37(1), 51-55.

Brouwer, J., Paap, R. \& Viaene, J. M. A. (2008). The Trade and FDI Effects of EMU Enlargement. Journal of International Money and Finance, 27(2), 188-208

Brouthers, K. D. \& Hennart, J. (2007). Boundaries of the Firm: Insights from International Entry Mode Research. Journal of Management, 33(3), 395-425

Buckley, P. J. (1990). International investment, New York: Edward Elgar Calderon, C. \& Serven, L. (2008).Infrastructure and Economic Development in Sub-Saharan Africa, World Bank Policy Research Working Paper N. 4712.

Caves, R. E. (2007). Multinational enterprise and economic analysis (3rd Ed.) Boston: Cambridge University Press

Chakrabarti, A. (2001). The Determinants of Foreign Direct investment: Sensitivity Analyses of Cross Country Regressions. Kyklos, 54(1), 89-114

Cleeve, E. (2008). How Effective Are Fiscal Incentives to Attract FDI to Sub-Saharan Africa? The Journal of Developing Areas, 42(1), 135-153

Correa, C. M. \& Kumar, N. (2003). Protecting foreign investment: Implications of a WTO regime and policy options. London: Zed Books Ltd.

Culem, C. G. (1988). The Locational Determinants of Direct Investment among Industrialised Countries. European Economic Review, 32(4), 885-904.

Dunning, J. H. (1981). International production and the multinational enterprise. London: George Allen and Unwin.

Dunning, J. H. (1993). Multinational enterprises and the global economy. London: Addison-Wesley.

Dupasquier C. \& Osakwe P. N. (2006). Foreign direct investment in Africa: Performance, challenges, and responsibilities. Journal of Asian Economics, 17(3), 241-260.

El-Wassal, K. A. (2012). Foreign direct investment and economic growth in Arab Countries (1970-2008): an inquiry into determinants of growth benefits. Journal of Economic Development, 37(4), 79-100

Fedderke J. W. \& Romm A. T. (2006). Growth impact and determinants of foreign direct investment into South Africa, 1956-2003. Economic Modelling, 23(2), 738-760.

Granger, C. W. J. (1988). Some Recent Developments in the Concept of Causality. Journal of Econometrics, $39(4), 199-211$.

Hailu, Z. A. (2010). Demand Side Factors Affecting the Inflow of Foreign Direct Investment to African Countries: Does Capital Market Matter? International Journal of Business and Management, 5(5), 104116.

Harms, P. \& Lutz, M. (2006). Aid, Governance, and Private Foreign Investment. Economic Journal, 116(513), 773-790.

Hair, J. F., Anderson, R. E., Tatham, R. L. \& Black, W. C. (1998). Multivariate analysis, 5th ed., Englewood Cliffs: Prentice-Hall.

Hill, C. W. L. (2013). International business: Competing in the global marketplace (9th Ed.) McGraw-Hill: Irwin.

Johansen, S. \& Juselius, K. (1990). Maximum Likelihood Estimation and Inference on Cointegration-with Application to the Demand for Money. Oxford Bulletin of Economics and Statistics, 52(2), 169-210

Kimura, H. \& Todo, Y. (2010). Is Foreign Aid a Vanguard of Foreign Direct Investment? A Gravity-Equation Approach. World Development, 38(4), 482-497.

Kinda, T. (2010). Investment Climate and FDI in Developing Countries: Firm-Level Evidence. World Development, 38(4), 498-513.

Kok, R. \& Ersoy, B. A. (2009). Analysis of FDI Determinants in Developing Countries. International Journal of Social Economics, 36(1/2), 105-123.

Kyereboah-Coleman, A. \& Agyire-Tettey K. F. (2008). Effect of Exchange-Rate Volatility on Foreign Direct Investment in Sub-Saharan Africa: The Case of Ghana (Case study). Journal of Risk Finance, 9(1), 52 70 
Lall, P., Norman, D. W. \& Featherstone, A. M. (2003). Determinants of US Direct Foreign Investment in the Caribbean. Applied Economics, 35(13), 1485-1496.

Lee, H. H. \& Tan, H. B. (2006). Technology Transfer, FDI and Economic Growth in the ASEAN Region. Journal of the Asia Pacific Economy, 11(4), 394-410

Levi, M. D. (2009). International finances (5th Ed.) London: Routledge.

Levin, A., Lin, C. \& Chu, C. J. (2002). Unit Root Tests in Panel Data: Asymptotic and Finite-Sample Properties. Journal of Econometrics, 108, 1-24.

Mohamed, S. E. \& Sidiropoulos, M. G. (2010). Another Look at the Determinants of Foreign Direct Investment in MENA Countries: An Empirical Investigation. Journal of Economic Development, 35(2), 75-96.

Nnadozie E. \& Osili U. O. (2004). U.S. Foreign Direct Investment in Africa and its Determinants. UNECA Workshop of Financial Systems and Mobilization in Africa, Nov 2nd

Nonnemberg, M. B. \& Cardoso de Mendonça, M. J. (2004). The Determinants of Foreign Investment in Developing Countries. Downloaded from: http://www.anpec.org.br/encontro2004/artigos/A04A061.pdf as at 28th Jan. 2014

Oladipo, O. S. (2008). Foreign Direct Investment Flow: Determinants and Growth Effects in a Small Open Economy, Proceedings of the Northeast Business \& Economics Association, Northeast Business \& Economics Association 35th Annual Conference, Long Island, New York, November 6th - 8th.

Pantelidis, P. \& Nikopoulos, E. (2008). FDI Attractiveness in Greece. International Advances Economic Research, 14(3), 90-100.

Pantelidis, P., Kyrkilis, D. \& Nikolopoulos, E. (2012). European Monetary Union and Foreign Direct Investment Inflows. SPOUDAI Journal of Economics and Business, 62 (2), 47-55.

Pelinescu, E. (2015). The impact of human capital on economic growth. Procedia Economics and Finance, 22(1), 184-190.

Peng, M. W. (2009). Global business. New York: South-Western Cengage Learning. Ponce, A.F. (2006). Openness and Foreign Direct Investment: The Role of Free Trade Agreements in Latin America. MPRA Paper No. 8858:1-26.

Porter, M. E. (1990). The comparative advantage of nations. New York: Free Press.

Reiter, S. L., Rivera-Batiz, L. A. \& Oliva, M. A. (2010). Human Development and Foreign Direct Investment in Developing Countries: The Influence of FDI Policy and Corruption. World Development, 38(12), 16781691.

Schmitz, H. (2007). Reducing Complexity in the Industrial Policy Debate. Development Policy Review, 25(4), 417-428.

Steers, M. R. \& Nardon, L. (2006). Managing in the global economy. New York: M.E. Sharpe, Inc.

Stiglitze, J. E. (2002). Globalization and its discontents. New York: W.W. Norton \& Company.

Stiglitz, J. E. \& Charlton, A. (2005). Fair trade for all. New York: Oxford University Press

Sekkat, K. \& Veganzones-Varoudakis, M. A. (2007). Openness, Investment Climate, and FDI in Developing Countries. Review of Development Economics, 11(4), 607-620.

Tsai, P. (1994). Determinants of Foreign Direct Investment and its Impact on Economic Growth. Journal of Economic Development, 19(3), 137-63.

UNCTAD. (2009). World investment report. Transnational corporations, agricultural production and development. New York and Geneva: The United Nations

UNCTAD (2013). World investment report: Global value chains: Investment and trade for development. New York and Geneva: The United Nations Conference and Trade and Development.

UNCTAD. (2014). World investment report 2014. By United Nations Conference on Trade and Development, New York: United Nations

UNCTAD. (2015). World investment report 2015. By United Nations Conference on Trade and Development, New York: United Nations

Usman, A. \& Ibrahim, W. (2012). Foreign Direct Investment and Monetary Union in ECOWAS Sub-Region: Lessons from Abroad. Journal of Applied Finance \& Banking, 2(4), 185-192

Wheeler, D. \& Mody, A. (1992). International Investment Locational Decisions: The Case of US Firms. Journal of International Economics, 33(4), 57-76.

Yasin, M. (2005). Official Development Assistance and Foreign Direct Investment Flows to Sub- Saharan Africa. African Development Review, 17 (1), 23-40. 
Appendix A: List of Asian and African countries covered in the study

\begin{tabular}{|c|c|c|}
\hline $\mathrm{S} / \mathrm{N}$ & Asian Countries (Panel A) & African Countries (Panel B) \\
\hline 1 & Afghanistan & Algeria \\
\hline 2 & Armenia & Angola \\
\hline 3 & Azerbaijan & Benin \\
\hline 4 & Bahrain & Botswana \\
\hline 5 & Bangladesh & Burkina Faso \\
\hline 6 & Bhutan & Burundi \\
\hline 7 & Brunei & Cameroon \\
\hline 8 & Cambodia & Central African Republic \\
\hline 9 & China & Chad \\
\hline 10 & Cyprus & Congo Dem. Rep \\
\hline 11 & Georgia & Cote d'Ivoire \\
\hline 12 & India & Egypt \\
\hline 13 & Indonesia & Equatorial Guinea \\
\hline 14 & Iran & Ethiopia \\
\hline 15 & Iraq & Gabon \\
\hline 16 & Israel & Gambia \\
\hline 17 & Japan & Ghana \\
\hline 18 & Jordan & Guinea \\
\hline 19 & Kazakhstan & Guinea-Bissau \\
\hline 20 & Kuwait & Kenya \\
\hline 21 & Kyrgyzstan & Liberia \\
\hline 22 & Laos & Madagascar \\
\hline 23 & Lebanon & Malawi \\
\hline 24 & Malaysia & Mali \\
\hline 25 & Maldives & Mauritania \\
\hline 26 & Mongolia & Mauritius \\
\hline 27 & Myanmar & Morocco \\
\hline 28 & Nepal & Mozambique \\
\hline 29 & North Korea & Namibia \\
\hline 30 & Oman & Niger \\
\hline 31 & Pakistan & Nigeria \\
\hline 32 & Philippines & Rwanda \\
\hline 33 & Qatar & Senegal \\
\hline 34 & Saudi Arabia & Sierra Leone \\
\hline 35 & Singapore & South Africa \\
\hline 36 & South Korea & Sudan \\
\hline 37 & Sri Lanka & Swaziland \\
\hline 38 & Syria & Togo \\
\hline 39 & Tajikistan & Tunisia \\
\hline 40 & Thailand & Uganda \\
\hline 41 & & Zambia \\
\hline
\end{tabular}

